\title{
KONSEP DASAR ILMU GIZI
}

Andi Assyifa Mappedeceng Okarniatif

Universitas Islam Negeri Alauddin Makassar

Email : assyifaandi2812@gmail.com

\section{PENGERTIAN ILMU GIZI}

Beberapa ahli mendefinisikan ilmu gizi seperti menurut

Turner: Ilmu yang mempelajari segala sesuatu tentang makanan dalam hubungannya dengan kesehatan optimal.

Menurut Vrause: llmu Gizi adalah ilmu yang mempelajari makanan dalarn hubungannya dengan kesejahteraan tubuh meliputi kebutuhan makanan, nilai makanan, pemeliharaan rnakanan untuk golongan usia dan aktifitas tertentu.

Menurut Eva D. Wilson: 1lmu Gizi adalah ilmu yang mempelajari ten!ang tubuh yang terdiri dari jenis, jumlah dan materi yang harus dicukupi dalam makanan seharl-hari, guna pemeliharaan selsel tubuh.

Graham Lusk : berpendapat yang dimaksud dengan ilmu gizi adalah totalitas dari pada peristiwaperistiwa yang berhubungan dengan pertumbuhan, pemeliharaan dan perbaikan hidup dari tubuh secara keseluruhan.

Menurut Sunita Almatsier: llmu Gizi adalah ilmu yang mempelajari segala sesuatu tentang makanan dalam hubungannya dengan kesehatan optimal.

pengertian gizi secara klasik atau zaman dahulu gizi hanya dikaitkan dengan kesehatan tubuh saja. Artinya yang dikatakan gizi adalah aspek yang berhubungan dengan fungsi dasar zat gizi tersebut yaitu menghasilkan energi, pertumbuhan dan pemeliharaaan jaringan, serta mengatur proses metabolisme dalam tubuh. Pada zaman modern ini pengertian ilmu gizi tidak hanya sebatas fungsi dasar zat gizi dan kesehatan saja tetapi zat gizi sudah dihubungkan dengan kemampuan kerja, produktivitas, IQ, dan status ekonomi.Tujuan ilmu gizi sendiri adalah mencapai, memperbaiki, dan mempertahankan kesehatan tubuh melalui konsumsi makanan.

llmu gizi adalah ilmu yang mempelajari tentang hubungan makanan dengan kesehatan. llmu gizi meliputi ruang lingkup yang sangat luas. Ada berbagai bidang yang menyangkut ilmu gizi tersebut yaitu ilmu agronomi, peternakan, ilmu pangan, mikrobiologi, biokimia, faa, biologi mole uler dan kedokteran. llmu gizi juga berkaitan dengan ilmu-ilmu sosial seperti antropologi, sosiologi, psikologi dan ekonomi. 


\section{RUANG LINGKUP ILMU GIZI}

Ilmu gizi termuk sebagai salah satu cabang ilmu yang relatif masih baru. Ilmu gizi baru diakui sebagai ilmu pengetahuan (sains) pada awal abad 20. Hal ini setelah penemuan bidang-bidang ilmu lain khususnya di bidang ilmu kimia dan ilmu fisiologi. Selain itu penemuan-penemuan baru seperti vitamin, protein dan zat gizi lainnya yang menjadi dasar ilmu gizi.

Secara klasik kata gizi hanya dihubungkan dengan kesehatan tubuh, yaitu untuk menyediakan energi, membangun dan memelihara jaringan tubuh serta mengatur proses-proses kehidupan dalam tubuh. Tetapi sekarang kata gizi mempunyai pengertian yang lebih luas, di samping untuk kesehatan, gizi dikaitkan dengan potensi ekonomi seseorang karena gizi berkaitan dengan perkembangan otak, kemampuan belajar dan produktivitas kerja.

Ruang lingkup ilmu gizi cukup luas. Ilmu gizi mencakup banyak disiplin ilmu, mulai dari ilmu bahan makanan seperti cara produksi pangan, perubahan pascapanen (penyediaan pangan, distribusi dan pengolahan pangan, konsumsi makanan serta cara pemanfaatan makanan oleh tubuh yang sehat dan sakit). Ilmu gizi juga berkaitan dengan ilmu agronomi, peternakan, ilmu pangan, mikrobiologi, biokimia, faal, biologi molekular dan kedokteran.

\section{PENYEBAB GANGGUAN GIZI}

Kalau sudah mengetahui pengertian yang berkaitan dengan gizi, sekarang bagaimana masalah gizi bisa muncul?, ditinjau dari penyebabnya, gangguan gizi bisa dibagi menjadi penyebab dari faktor primer dan penyebab dari faktor sekunder. Baiklah, sekarang apakah yang disebut faktor primer itu ?, faktor primer maksudnya semua masalah gizi yang disebabkan susunan makanan salah, baik dalam hal kuantitas maupun kualitasnya. Faktor primer ini dapat meliputi; kurangnya penyediaan pangan, kurang baiknya distribusi pangan, kemiskinan, ketidaktahuan, dan kebiasaan makan salah. Jadi faktor yang menyebabkan tidak tersedianya makanan yang akan dimakan mulai dari hulu sampai hilir.

\section{PROSES PENCERNAAN MAKANAN PROSES PENCERNAAN MAKANAN PROSES PENCERNAAN MAKANAN}

Proses pencernaan makanan dilakukan oleh sistem pencernaan, silahkan mengingat kembali anatomi fisiologi dari sistem pencernaan. Proses ini meliputi pencernaan secara mekanik yang dilakukan oleh otot pengunyah, gigi, lidah, gerakan peristaltik saluran cerna yang membantu memecah makanan yang kita makan menjadi partikel yang lebih kecil selain itu juga dibantu dengan pencernaan kimiawi yang dilakukan oleh enzim-enzim pencernaan yang memecah karbohidrat dalam makanan menjadi bentuk karbohidrat yang paling sederhana yaitu monosakarida, memecah protein menjadi asam amino dan memecah lemak menjadi asam lemak dan gliserol. Setelah makanan dicerna menjadi bentuk yang paling sederhana, maka partikel zat gizi yang terbentuk mengalami penyerapan atau absorbsi. 


\section{JENIS-JENIS ZAT GIZI JENIS ZAT GIZI JENIS ZAT GIZI}

\section{KARBOHIDRAT}

Baiklah kita mulai saja dengan karbohidrat. Karbohidrat yaitu senyawa organik terdiri dari unsur karbon $(\mathrm{C})$, hidrogen $(\mathrm{H})$, dan oksigen $(\mathrm{O})$. Karbohidrat banyak terdapat pada tumbuhan dan binatang. Pada tumbuhan sintesis $\mathrm{CO} 2+\mathrm{H} 2 \mathrm{O}$ akan menghasilkan amilum selulosa melalui proses fotosintesis. Banyak sekali makanan yang kita makan sehari-hari adalah sumber karbohidrat seperti : nasi/ beras, singkong, umbi-umbian, gandum, sagu, jagung, kentang, dan beberapa buah-buahan lainnya. Rumus umum karbohidrat yaitu $\mathrm{CnH} 2 \mathrm{nOn}$, contoh susunan kimia karbohidrat sebagai berikut.

Fungsi Karbohidrat

Sebagai Sumber Energi

Fungsi utama karbohidrat adalah menyediakan energi bagi tubuh. Karbohidrat merupakan sumber energi utama bagi seluruh penduduk dunia karena relatif terjangkau dan mudah didapatkan.

Sebagai Pemberi Rasa Manis pada Makanan

Fungsi karbohidrat berikutnya adalah memberi rasa manis pada makanan, khususnya monosakarida dan disakarida.

Sebagai Penghemat Protein

Bila kebutuhan karbohidrat makanan tidak mencukupi, maka protein akan digunakan sebagai cadangan makanan untuk memenuhi kebutuhan energi dan mengalahkan fungsi utamanya sebagai zat pembangun.

Sebagai Pengatur Metabolisme Lemak

Karbohidrat mencegah terjadinya oksidasi lemak yang tidak sempurna yang dapat menghasilkan bahan-bahan keton yang dapat berbahaya.

Membantu Pengeluaran Feses

Karbohidrat dapat membantu proses pengeluaran feses dengan cara mengatur peristaltik usus, hal ini didapat dari selulosa dalam serat makanan yang berfungsi mengatur peristaltik usus.

Lemak

Lemak atau lipid adalah senyawa organik yang larut dalam pelarut non polar seperti etanol, kloroform dan benzena, tetapi tidak larut dalam air. Lemak mengandung karbon, hidrogen dan oksigen. Walaupun elemen-elemen ini juga menyusun karbohidrat, perbandingan oksigen 
terhadap karbon dan hidrogen lebih rendah pada lemak. Karena lemak lebih sedikit mengandung oksigen, kalori yang dihasilkannya dua kali lebih banyak daripada karbohidrat dalam jumlah yang sama. Tubuh banyak mendapat lemak dari makanan yang dikonsumsi, tetapi tubuh juga membentuk beberapa lemak.

\section{Protein}

Protein adalah molekul makro yang mempunyai berat molekul antara lima ribu hingga beberapa juta. Protein terdiri atas rantairantai panjang asam amino yang terikat satu sama lain dalam ikatan peptide. Asam amino terdiri atas unsur-unsur karbon, hidrogen, oksigen dan nitrogen.

\section{Vitamin}

Vitamin adalah senyawa organik yang tersusun dari karbon, hidrogen, oksigen, dan terkadang nitrogen atau elemen lain yang dibutuhkan dalam jumlah kecil agar metabolisme, pertumbuhan dan perkembangan berjalan normal. Jenis nutrien ini merupakan zat-zat organik yang dalam jumlah kecil ditemukan pada berbagai macam makanan. Vitamin tidak dapat digunakan untuk menghasilkan energi .

\section{Mineral}

Mineral merupakan bagian dari tubuh yang memegang peranan penting dalam pemeliharaan fungsi tubuh, baik pada tingkat sel, jaringan organ maupun fungsi tubuh secara keseluruhan. Mineral merupakan komponen inorganik yang terdapat dalam tubuh manusia. Sumber paling baik mineral adalah makanan hewani, kecuali magnesium yang lebih banyak terdapat di alam makanan nabati. Hewan memperoleh mineral dari tumbuhtumbuhan dan menumpuknya di jaringan tubuhnya.

\section{FUNGSI ZAT GIZI}

- Sebagai sumber energy

- Menggerakkan tubuh dan proses metabolism di dalam tubuh

- Mempunyai ikatan organik mengandung karbon yang dapat dibakar

- Untuk pertumbuhan dan mempertahankan jaringan

- Berfungsi sebagai pembentuk sel-sel pada jaringan tubuh

- Sebagai pengatur atau regulasi proses dalam tubuh

- Yaitu protein, vitamin, mineral, dan air

- Protein membentuk antibody

- Protein mengatur keseimbangan air dalam tubuh

- Vitamin dan mineral sebagai pengatur fungsi saraf dan otot. 


\section{Referensi}

Alam, S., \& Kartini, T. A. (2021). Islamic Parenting "Pola Asuh Anak: Tinjauan Perspektif Gizi Masyarakat". Repository UIN Alauddin Makassar.

Anonymous. (September 2015). Buku Ajar Dasar-Dasar Ilmu Gizi G006. Denpasar: Universitas Udayana.

Mardelena, I., \& Suryani, E. (Desember 2016). Modul Bahan Ajar Cetak Keperawatan IImu Gizi. Jakarta Selatan: Kementerian Kesehatan Republik Indonesia.

Setyawati, V. A., \& hartini , E. (Agustus 2018). Buku Ajar Dasar Ilmu Gizi Kesehatan Masyarakat. Yogyakarta: Deepublish.

Stafrizal, \& Wetis, W. (Agustus 2008). Ilmu Gizi. Malang: Wineka Media.

Auliana, R. Konsep Dasar Ilmu Gizi diakses dari

http://staff.uny.ac.id/sites/default/files/pendidikan/Rizqie\%20Auliana,Dra.\%20\%20M.Kes./ILMU\%20GIZ I-KONSEP\%20DASAR\%20\&\%20KARBOHIDRAT.pdf pada tanggal 6 Juni 2021. 